\title{
Review
}

\section{Randomized Clinical Trials on Acupuncture in Korean Literature: A Systematic Review}

\section{Jae Cheol Kong', Myeong Soo Lee ${ }^{2,3}$ and Byung-Cheul Shin ${ }^{1}$}

${ }^{1}$ Department of Oriental Rehabilitation Medicine, College of Oriental Medicine, Wonkwang University, Iksan, South Korea, ${ }^{2}$ Complementary Medicine, Peninsula Medical School, Universities of Exeter and Plymouth, Exeter, UK and ${ }^{3}$ Department of Medical Research, Korea Institute of Oriental Medicine, Daejeon, South Korea

The aim of this systematic review was to summarize randomized clinical trials (RCTs) assessing the effectiveness of acupuncture as published in Korean literature. Systematic searches were conducted on eight Korean medical databases. Manual searches were also conducted through eight major Korean medical journals. The methodological quality was assessed using a Jadad score. Studies evaluating needle acupuncture or auricular acupuncture (AA) with or without electrical stimulation were considered if they were sham or placebo-controlled or controlled against a comparative intervention. We also excluded acupuncture as an adjuvant to other treatments and other forms of acupuncture were excluded. Seven hundred and nine possibly relevant studies were identified and 10 RCTs were included. The methodological quality of the trials was generally poor. Manual acupuncture was compared to placebo acupuncture in four studies of patients with chronic low back pain, shoulder pain, premenstrual syndrome and allergic rhinitis. Three studies tested AA (two trials) and electroacupuncture (one trial) against no treatment, while three trials compared acupuncture with other active therapeutic controls. The methodological limitations of the included trials make their contribution to the current clinical evidence of acupuncture somewhat limited. The trial for premenstrual syndrome, shoulder pain and chronic low back pain added a limited contribution among those included RCTs. However, well-designed RCTs of acupuncture with a rigorous methodology are in progress or have been completed in Korea and will contribute to establish or contribute to the current progress of research in this field.

Keywords: acupuncture - clinical trial - Korean medicine - systematic review

\section{Introduction}

Acupuncture can be defined as the insertion of needles into the skin and underlying tissues at particular sites, known as points, for therapeutic or preventive purposes (1). The points can also be stimulated with electricity, lasers, pressure, heat or ultrasound waves (1).

For reprints and all correspondence: Byung-Cheul Shin, OMD, PhD, LAc, Department of Oriental Rehabilitation Medicine, College of Oriental Medicine, Wonkwang University, Iksan, 570-749, South

Korea. Tel: +82-63-859-2807; Fax: + 82-63-841-0033;

E-mail: shinbc@wonkwang.ac.kr; shinbc@hanmail.net

The first two authors contributed equally to this study.
Acupuncture is now a widely accepted intervention for the treatment of a variety of conditions, many of which are associated with pain (2).

Classical acupuncture, which originated in China, is used for treating various conditions in Korea (3). While maintaining a close relationship with China, however, Korea has continued to develop a unique medicine of its own over time and established different types of acupuncture methods from those used in traditional Chinese medicine $(3,4)$. Numerous clinical studies using acupuncture have been performed to demonstrate its efficacy in many types of disease, including pain conditions, stroke and facial palsy (3). 
A recently published Korean review summarized the clinical effectiveness of acupuncture (3). However, they did not include references to other recent studies or a systematic assessment. Moreover, many Korean studies have not included western databases, even though many Korean clinical trials on acupuncture have been reported in western journals. Therefore, as systematic reviews should include all relevant trials, regardless of their language, it is necessary to summarize randomized clinical trials (RCTs) in Korean literature for future systematic approaches on the effectiveness of acupuncture. The aim of this systematic review was to summarize RCTs assessing the effectiveness of acupuncture as published in Korean literature.

\section{Methods}

\section{Data Sources}

The computerized Korean databases listed in Table 1 were searched from their respective inceptions up to May 2007. The search terms used were 'acu', 'acupuncture' and random or Korean language terms related to acupuncture and clinical trials. Several specialized journals were also manually searched for relevant articles (Table 1).

\section{Study Selection}

Studies testing with needle acupuncture with or without electrical stimulation were included. We also include any form of auricular acupuncture (AA). Trials testing other forms of acupuncture, such as laser acupuncture or acupuncture using moxibustion or Transcutaneous Electrical Nerve Stimulator (TENS) were excluded. Studies comparing two different forms of acupuncture and those in which no data were reported were also excluded. We also excluded acupuncture as an adjuvant to other treatments, bee-venom therapy and herbal acupuncture, in which potentially pharmacologically active substances are injected at the acupuncture points. The control interventions were other active intervention without acupuncture or placebo acupuncture or no intervention.

The main outcome measures considered were the efficacy of acupuncture for treating the relevant condition. Trials were excluded if the outcomes related only to immunological or biological parameters, and if the subjects are healthy participants. Hardcopies of all articles were obtained and read in full.

\section{Data Extraction and Quality Assessment}

All articles were read by two independent reviewers (JCK, MSL), and data from the articles were validated

Table 1. The list of databases and journals (hand searched) searched in the course of this review

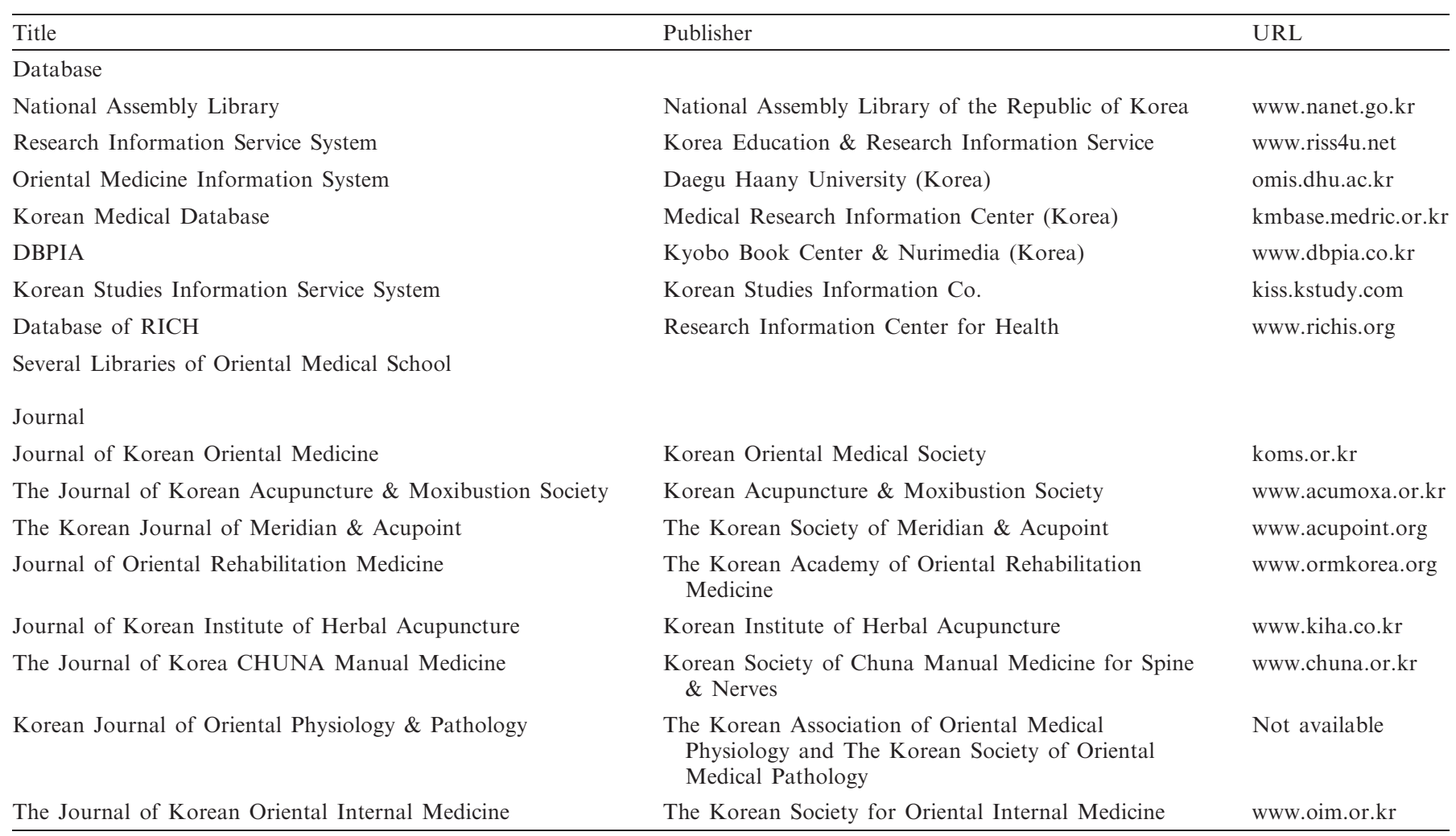


and extracted according to predefined criteria. Since it is virtually impossible for an acupuncturist to be blinded to the treatment, we employed a modified version of the Jadad score $(5,6)$. Points were awarded as follows: study described as randomized, 1 point; appropriate randomization method, 1 point; inappropriate randomization method, 1 point deducted; patient blinded to intervention, 1 point; evaluator blinded to intervention, 1 point and description of withdrawals and dropouts, 1 point. The highest possible score was 5 points. Patient blinding was assumed where the control intervention was indistinguishable from acupuncture, even if the word 'blinding' did not occur in the report. The point for evaluator blinding was only given if specified in the text. Trials with 4 or 5 points were considered to be of high quality. Allocation concealment was assessed using the Cochrane classification (7). Discrepancies were resolved by discussion between the two reviewers (JCK, MSL) via E-mail and telephone, and if needed, by seeking the opinion of the third reviewer (BCS).

The quality of acupuncture was assessed by two reviewers (JCK, BCS), who are certified Korean oriental medical doctors, according to previous study (8). Discrepancies were resolved by discussion. They answered for the question, "how would you treat the patients included in the study?', on five categories including 'exactly or almost exactly the same way', 'similarly', 'differently', 'completely differently', or 'could not assess' due to insufficient information (on acupuncture or on the patient). The degree of confidence that acupuncture was applied in an appropriate manner was assessed on the $100 \mathrm{~mm}$ visual analog scale (with $0 \%=$ complete absence of evidence that the acupuncture was appropriate, and $100 \%=$ total certainty that the acupuncture was appropriate).

\section{Results}

\section{Study Description}

The searches identified 709 potentially relevant studies, of which 10 met our inclusion criteria (Fig. 1). The key data are summarized in Table 2. Excluded non-randomized controlled clinical trials (CCTs) and their reasons for exclusion are summarized in Supplement 1, while the details of excluded RCTs were summarized in Supplement 2. The treated conditions were insomnia (one trial), postoperative nausea and vomiting (one trial), temporomandibular disorder (TMD) (one trial), allergic rhinitis (one trial), premenstrual syndrome (one trial), frozen shoulder (one trial), chronic low back pain (one trial), chronic headache (one trial), post-thoracotomy pain (one trial) and dysmenorrhea (one trial). The acupuncture techniques used were AA (two trials), electroacupuncture (EA) (one trial) and classic acupuncture (seven trials). Regarding types of control, a placebo procedure was employed in four trials (9-12), other therapeutic methods in three trials (13-15) and no treatment in three other trials (16-18).

\section{Study Quality and Acupuncture Validity}

The methodological quality of the trials was poor. Only three $(9,10,12)$ of the 10 RCTs exhibited a Jadad score above three, one trial (10) described the methods of randomization, none described allocation concealment. Only two of the included RCTs described subject and evaluator blinding $(10,12)$, while one other described subject and acupuncturist blinding (9). One trial reported subject blinding (11). Sufficient details on dropouts and withdrawals were described in four trials $(9,10,14,15)$. Adverse events and ethical approval procedures were mentioned in only two $(10,12)$ and four trials $(9-12)$, respectively.

Regarding the quality of acupuncture, the authors would have treated the patients completely differently $(15,18)$ in two trials, similarly in three trials $(9,10,13)$ and exactly $(11,16,17)$ or almost exactly the same way $(12,14)$ in

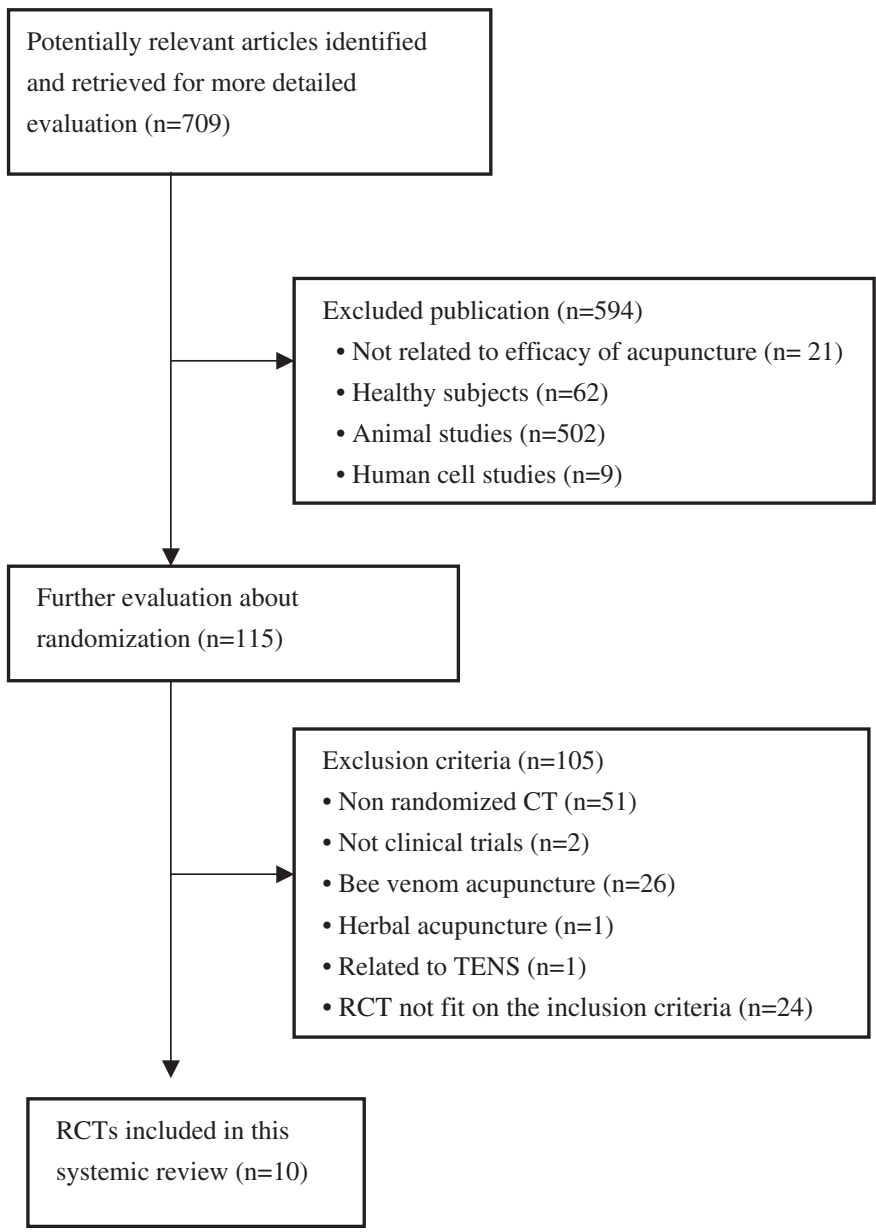

Figure 1. Flowchart of trial selection process. 
Table 2. Key data of RCTs of acupuncture in Korean literatures

\begin{tabular}{|c|c|c|c|c|c|c|c|c|}
\hline $\begin{array}{l}\text { First } \\
\text { author } \\
\text { (Year) } \\
\text { (Ref) }\end{array}$ & $\begin{array}{l}\text { Conditions } \\
\text { Sample size } \\
\text { (randomized/ } \\
\text { analysed) }\end{array}$ & $\begin{array}{l}\text { Study design Quality } \\
\text { score, }{ }^{\mathrm{a}} \text { Acupuncture } \\
\text { validity score [quality of } \\
\text { acupuncture } \\
\text { confidence }^{\mathrm{b}} \text {, degree of allocation } \\
\text { concealment }^{\mathrm{d}}\end{array}$ & $\begin{array}{l}\text { Experimental } \\
\text { treatment (Regimen) }\end{array}$ & $\begin{array}{l}\text { Control treatment } \\
\text { (Regimen) }\end{array}$ & $\begin{array}{l}\text { Concomitant } \\
\text { treatment }\end{array}$ & Main outcomes & $\begin{array}{l}\text { Intergroup } \\
\text { difference }\end{array}$ & Authors conclusion \\
\hline $\begin{array}{l}\text { Sok } \\
(2000) \\
(18)\end{array}$ & $\begin{array}{c}\text { Insomnia } \\
74 / 74\end{array}$ & $\begin{array}{l}2 \text { parallel arms } 1,[1,15 \%] \text {, } \\
\text { unclear }\end{array}$ & $\begin{array}{l}\text { AA ( } 1 \text { time, retain } \\
\text { for } 4 \text { days, } \\
\text { thumbtack-type } \\
\text { needle), plus } \\
\text { press }(1 \sim 2 \text { min, } \\
3 \text { times daily for } \\
4 \text { days, } n=37)\end{array}$ & $\begin{array}{l}\text { No treatment } \\
\quad(n=37)\end{array}$ & n.r. & $\begin{array}{l}\text { (1) Sleep quality } \\
\text { (2) Self-satisfaction } \\
\text { (Sleep) }\end{array}$ & $\begin{array}{l}\text { (1) } P<0.001 \\
\text { (2) } P<0.001\end{array}$ & $\begin{array}{l}\text { 'Auricular acupuncture } \\
\text { can reduce the fre- } \\
\text { quent insomnia of the } \\
\text { elderly and increase } \\
\text { the satisfaction they } \\
\text { find in sleep.' }\end{array}$ \\
\hline $\begin{array}{l}\text { Kim } \\
(1996) \\
(16)\end{array}$ & $\begin{array}{l}\text { Post-operative } \\
\text { nausea and } \\
\text { vomiting } \\
100 / 100\end{array}$ & $\begin{array}{l}2 \text { parallel arms } 1,[4,95 \%] \text {, } \\
\text { unclear }\end{array}$ & $\begin{array}{l}\text { AA (thumbtack-type } \\
\text { needle, } n=50 \text { ) }\end{array}$ & $\begin{array}{l}\text { No treatment } \\
\quad(n=50)\end{array}$ & n.r. & $\begin{array}{l}\text { (1) Incidence of } \\
\text { vomiting/ } \\
\text { retching, or } \\
\text { nausea }\end{array}$ & (1) $P<0.01$ & $\begin{array}{l}\text { 'Auricular acupuncture } \\
\text { is effective in } \\
\text { reducing nausea and } \\
\text { vomiting after trans- } \\
\text { abdominal hysterect- } \\
\text { omy in female } \\
\text { patients.' }\end{array}$ \\
\hline $\begin{array}{l}\text { Park } \\
(1999) \\
(17)\end{array}$ & $\begin{array}{l}\text { Temporomandib- } \\
\text { ular disorder } \\
38 / 38\end{array}$ & $\begin{array}{l}2 \text { parallel arms } 1,[4,90 \%] \\
\text { unclear }\end{array}$ & $\begin{array}{c}\text { EA }(3-15 \mathrm{~Hz}, 20 \mathrm{~min}, \\
3 \text { times weekly for } \\
2 \text { weeks, } n=28)\end{array}$ & $\begin{array}{l}\text { No-treatment } \\
\quad(n=10)\end{array}$ & None & $\begin{array}{l}\text { (1) Pain (Numeric } \\
\text { analog scale) } \\
\text { (2) Maximal } \\
\text { mouth opening }\end{array}$ & $\begin{array}{l}\text { (1) } P<0.05 \\
\text { (2) NS }\end{array}$ & $\begin{array}{l}\text { 'The clinical indexes of } \\
\text { the treated patient } \\
\text { group are more sig- } \\
\text { nificantly changed } \\
\text { than those of the non- } \\
\text { treated patient group.' }\end{array}$ \\
\hline $\begin{array}{l}\text { Park } \\
(2005) \\
(12)\end{array}$ & $\begin{array}{l}\text { Allergic rhinitis } \\
101 / 101\end{array}$ & $\begin{array}{l}2 \text { parallel arms (subject } \\
\text { and evaluator blinding) } \\
3,[4,85 \%] \text {, unclear }\end{array}$ & $\begin{array}{l}\text { AT }(15 \mathrm{~min} \text {, one } \\
\text { time, } n=50)\end{array}$ & $\begin{array}{l}\text { Placebo AT on } \\
\text { non acupunc- } \\
\text { ture point, } \\
\text { (15 min, one } \\
\text { time, } n=51)\end{array}$ & None & $\begin{array}{l}\text { (1) Total nasal } \\
\text { volume } \\
\text { (2) Total nasal } \\
\text { minimum cross- } \\
\text { sectional area }\end{array}$ & $\begin{array}{l}\text { (1) NS at } \\
\text { immediate } \\
\text { after, after } \\
7.5 \mathrm{~min}^{\mathrm{and}} \\
15 \mathrm{~min}^{\mathrm{e}} \\
\text { (2) } P<0.05 \\
\text { after } 15 \mathrm{~min}^{\mathrm{e}}\end{array}$ & $\begin{array}{l}\text { 'Acupuncture reduces } \\
\text { nasal obstruction due } \\
\text { to persistent allergic } \\
\text { rhinitis' }\end{array}$ \\
\hline $\begin{array}{l}\text { Kim } \\
(2005) \\
(9)\end{array}$ & $\begin{array}{l}\text { Premenstrual } \\
\text { syndrome } \\
20 / 13\end{array}$ & $\begin{array}{l}2 \text { parallel arms (subject } \\
\text { and acupuncturist blind- } \\
\text { ing) } 4,[3,75 \%] \text {, unclear }\end{array}$ & $\begin{array}{l}\text { AT (n.r., } 2 \text { times } \\
\text { weekly for } \\
\text { 8weeks, } n=\text { n.r.) }\end{array}$ & $\begin{array}{l}\text { Placebo AT on } \\
\text { acupuncture } \\
\text { point (n.r., } 2 \\
\text { times weekly } \\
\text { for } 8 \text { weeks, } \\
n=\text { n.r.) }\end{array}$ & None & $\begin{array}{l}\text { (1) Menstrual } \\
\text { symptom } \\
\text { severity }\end{array}$ & (1) $P<0.05$ & $\begin{array}{l}\text { 'Acupuncture results in } \\
\text { significant improve- } \\
\text { ment in physical and } \\
\text { psychological symp- } \\
\text { toms compared to } \\
\text { placebo treatment.' }\end{array}$ \\
\hline $\begin{array}{l}\text { Lee } \\
(2006) \\
(11)\end{array}$ & $\begin{array}{l}\text { Frozen shoulder } \\
\quad 86 / 85\end{array}$ & $\begin{array}{l}3 \text { parallel arms (subject } \\
\text { blinding) 2, [4, 90\%], } \\
\text { unclear }\end{array}$ & $\begin{array}{l}\text { (A) AT (nearby } \\
\text { acupuncture } \\
\text { point, } 30 \text { min, } \\
3 \text { times weekly for } \\
4 \text { weeks, } n=28 \text { ) } \\
\text { (B) AT } \\
\text { [(A) }+ \text { remote } \\
\text { acupuncture } \\
\text { point, } 30 \mathrm{~min}, 3\end{array}$ & $\begin{array}{l}\text { Placebo AT on } \\
\text { non acupunc- } \\
\text { ture point, } \\
(30 \text { min, } 3 \text { times } \\
\text { weekly for } 4 \\
\text { weeks, } n=29)\end{array}$ & n.r. & $\begin{array}{l}\text { (1) Pain (VAS) } \\
\text { (2) Shoulder Pain } \\
\text { and Disability } \\
\text { Index } \\
\text { (3) Patient's } \\
\text { Global } \\
\text { Assessment } \\
\text { (4) ROM }\end{array}$ & $\begin{array}{l}\text { (1)-(3) NS } \\
\text { (4) NS, (A) vs. } \\
\text { control } \\
P<0.05 \text {, } \\
\text { external } \\
\text { rotation of } \\
\text { upper arm: } \\
\text { (B) vs. } \\
\text { control }\end{array}$ & $\begin{array}{l}\text { 'Acupuncture at both } \\
\text { remote and nearby } \\
\text { acupoints may be } \\
\text { effective in improving } \\
\text { external rotation of } \\
\text { frozen shoulder.' }\end{array}$ \\
\hline
\end{tabular}




\begin{tabular}{|c|c|c|c|c|c|c|c|c|}
\hline $\begin{array}{l}\text { Kwon } \\
(2007) \\
(10)\end{array}$ & $\begin{array}{l}\text { Chronic low back } \\
\text { pain } \\
50 / 50\end{array}$ & $\begin{array}{l}2 \text { parallel arms (subject } \\
\text { and evaluator blinding) } \\
5,[3,75 \%], \text { unclear }\end{array}$ & $\begin{array}{l}\text { AT }(20 \text { min, } 3 \text { times } \\
\text { weekly for } 4 \\
\text { weeks, } n=25)\end{array}$ & $\begin{array}{l}\text { Placebo AT on } \\
\text { non acupunc- } \\
\text { ture point, } \\
(20 \text { min, } 3 \text { times } \\
\text { weekly for } \\
4 \text { weeks, } n=25)\end{array}$ & n.r. & $\begin{array}{l}\text { (1) Pain (VAS) } \\
\text { (2) Ronald dis- } \\
\text { ability index }\end{array}$ & $\begin{array}{l}\text { (1) NS } \\
\text { (2) NS }\end{array}$ & $\begin{array}{l}\text { 'The manual acupunc- } \\
\text { ture is effective for } \\
\text { chronic low back } \\
\text { pain, compared } \\
\text { with the sham } \\
\text { acupuncture.' }\end{array}$ \\
\hline $\begin{array}{l}\text { Choi } \\
(2005) \\
(14)\end{array}$ & $\begin{array}{l}\text { Chronic headache } \\
86 / 51\end{array}$ & $\begin{array}{l}2 \text { parallel arms } 2,[4,90 \%] \text {, } \\
\text { unclear }\end{array}$ & $\begin{array}{l}\text { AT }(20 \text { min, } 2 \text { times } \\
\text { weekly for } 4 \\
\text { weeks, } n=43)\end{array}$ & $\begin{array}{l}\text { Stellate ganglion } \\
\text { block therapy } \\
(2 \text { times weekly } \\
\text { for } 4 \text { weeks, } \\
n=43)\end{array}$ & None & $\begin{array}{l}\text { (1) Pain (VAS) } \\
\text { (2) Pain (Brief } \\
\text { Pain Inventory) }\end{array}$ & $\begin{array}{l}\text { (1) NS } \\
\text { (2) NS }\end{array}$ & $\begin{array}{l}\text { 'The four-week acu- } \\
\text { puncture and stellate } \\
\text { ganglion block ther- } \\
\text { apy in chronic head- } \\
\text { ache patients is } \\
\text { effective for reducing } \\
\text { headache.' }\end{array}$ \\
\hline $\begin{array}{l}\text { Cho } \\
(1997) \\
(13)\end{array}$ & $\begin{array}{l}\text { Post-thoracotomy } \\
\text { pain } \\
20 / 20\end{array}$ & $\begin{array}{l}2 \text { parallel arms } 1,[3,85 \%] \text {, } \\
\text { unclear }\end{array}$ & $\begin{array}{l}\text { AT }(20-30 \text { min one } \\
\text { time and retain it } \\
\text { for } 2 \text { day, } n=10)\end{array}$ & $\begin{array}{l}\text { Analgesic treat- } \\
\text { ment group } \\
(n=10)\end{array}$ & NSAID & $\begin{array}{l}\text { (1) Pain (Lickert } \\
\text { scales) } \\
\text { (2) Limitation of } \\
\text { motion } \\
\text { (3) Analgesics } \\
\text { requirement }\end{array}$ & $\begin{array}{l}\text { (1), (2) NS } \\
\text { (3) } P<0.05\end{array}$ & $\begin{array}{l}\text { 'Acupuncture is an } \\
\text { effective method by } \\
\text { which to control post- } \\
\text { thoracotomy pain and } \\
\text { it is safer than } \\
\text { analgesics.' }\end{array}$ \\
\hline $\begin{array}{l}\text { Yuk } \\
(2005) \\
(15)\end{array}$ & $\begin{array}{l}\text { Primary dysme- } \\
\text { norrhea } \\
22 / 17\end{array}$ & $\begin{array}{l}\text { Cross-over 2, }[1,40 \%], \\
\quad \text { unclear }\end{array}$ & $\begin{array}{l}\text { AT }(20 \text { min, total } 2 \\
\quad \text { or } 3 \text { times, } n=17)\end{array}$ & $\begin{array}{l}\text { Herbal medicine } \\
\quad(3 \text { times daily } \\
\text { for } 5 \text { days, } \\
n=17)\end{array}$ & n.r. & (1) Pain (VAS) & (1) NS & $\begin{array}{l}\text { 'The acupuncture or } \\
\text { herbal medicine } \\
\text { during the } 5 \text { or } 7 \text { days } \\
\text { before menstruation } \\
\text { will be efficacious } \\
\text { against primary } \\
\text { dysmenorrheal' }\end{array}$ \\
\hline
\end{tabular}

AA: auricular acupuncture; AT: classic acupuncture; EA: electroacupuncutre; n.r.: not reported; NS: not significant; ROM: range of motion; VAS: visual analogue scale. ${ }^{\mathrm{a}}$ Quality score: Jadad score.

${ }^{\mathrm{b}}$ Quality of acupuncture: 0 , could not assess; 1 , completely differently; 2, differently; 3, similarly; 4, exactly or almost exactly the same way.

${ }^{\mathrm{c}}$ Degree of confidence: degree of confidence that acupuncture was applied appropriate manner $100 \mathrm{~mm}$ visual scale (with $0 \%=$ complete absence of evidence that the acupuncture was appropriate, and $100 \%=$ total certainty that the acupuncture was appropriate) please see supplement 3 for details.

${ }^{\mathrm{d}}$ Classified by Cochrane criteria: adequate, unclear, inadequate, or not used.

${ }^{\mathrm{e}}$ Authors did not report the intergroup difference. We have calculated the intergroup difference with their reported values. 
four trials. The degree of confidence that acupuncture was applied appropriately ranged from 15 to $95 \%$.

\section{Outcomes}

\section{Acupuncture methods versus placebo acupuncture}

Four studies compared the effects of classic acupuncture with placebo acupuncture on allergic rhinitis (12), premenstrual syndrome (9) shoulder pain (11) and chronic low back pain (10). Acupuncture reduced the pain associated with premenstrual syndrome, but failed to do so in frozen shoulder pain and chronic low back pain compared to that of the placebo controls. One time treatment improved total nasal minimum cross-sectional area after 15 min compared to placebo, while no intergroup differences were observed for total nasal volume.

\section{Comparison with no treatment}

Three trials tested AA $(16,18)$ and EA (17) versus no treatment. One study in this category showed better effectiveness of AA on the sleep quality of insomnia sufferers compared to no treatment (18). The other trial found that AA was superior to no treatment in terms of the incidence of vomiting, retching, or nausea (16). Further RCTs found favorable effects of EA on pain and limitation of motion in TMD patients compared to no treatment (17).

\section{Testing against other therapeutic methods}

Three RCTs compared acupuncture with stellateganglion-block (SGB) therapy (14), analgesic treatment (13) and herbal medicine (15) in treating several pain conditions including chronic headache, postthoracotomy pain and dysmenorrhea, respectively. None of them found a significant difference in pain between two treatments. Only one trial found acupuncture to reduce the analgesics requirement compared to analgesic treatment (13).

\section{Discussion}

This review involved a systematic assessment of RCTs related to the effectiveness of acupuncture by evaluating articles published in Korean literature. The trials assessed the efficacy of several types of acupuncture on various medical conditions. However, each trial involved only a small sample and short intervention time, while the methodological quality of the trials was low.

Of the 10 RCTs, only four trials were both patient and assessor blinded $(10,12)$ or both patient and acupuncturist blinded (9) or subject blinded (11), whereas six studies did not make any attempt at either subject or assessor blinding. Trials with inadequate levels of blinding are likely to show exaggerated treatment effects, thus limiting the reliability of the study results. The concealment of treatment allocation was not reported in all 10 trials. Also, the intervention period was short [once in each of four trials $(12,13,16,18)$ and twice in one trial (14)]. A matter of concern is the reporting of details of ethical approval and adverse events. Four trials reported the ethical approval (9-12), while two reported adverse events $(10,12)$.

It is meaningful to compare which discrepancies or agreements are shown for each condition in the included studies with the conclusions of previous systematic reviews. The evidence is scarce that $\mathrm{AA}$ and EA are more effective than no treatment for treating insomnia (18), post-operative nausea or vomiting (16) and TMD (17). We cannot completely elucidate placebo effects of acupuncture. Thus, they cannot influence the current level of evidence for these conditions. The four trials tested the effects of acupuncture on allergic rhinitis (12), premenstrual syndrome (9), shoulder pain (11) and chronic low back pain (10) as compared to placebo acupuncture. The RCT-tested effects of acupuncture on allergic rhinitis showed it to be beneficial for the reduction of nasal obstructions (12). Even though this showed significant difference at $15 \mathrm{~min}$ after acupuncture, uncertainty of effectiveness remains by one-time treatment and short-time follow-up measurements. Hence, it cannot contribute to current evidence. The other RCT, which assessed the effects of acupuncture on premenstrual syndrome, reported positive results on the reduction of menstrual symptom severity (9). This can add positive effects to the current evidence $(2,19)$. However, the included sample size was too small and the contribution limited. The other RCT, which tested effects of acupuncture on chronic low back pain (10), failed to show positive results. This was contradicting to current positive evidence $(2,19)$ and made it to a more negative direction. Further RCT, which assessed effects of acupuncture on shoulder pain (11), failed to show positive results. This can add more evidence to current evidence of this condition, which reported no effectiveness of acupuncture (2). One trial tested the effects of acupuncture on post-thoracotomy pain compared to analgesic treatment (13). The results showed the favorable effect of acupuncture on the analgesics requirement, but with no significant difference on pain. There was no systematic review on post-operative pain control with acupuncture. One review suggested that acupuncture may be effective for post-operative analgesic consumption (20). This trial may contribute more evidence in the future systematic reviews, but the small sample size provides a limited contribution. Furthermore, the RCT assessed the effects of acupuncture on primary dysmenorrhea compared to herbal medicine (15). This trial comparing the effects with any of the two cannot be informative. 
Most of the excluded RCTs tested the effectiveness of particular acupuncture methods or compared certain treatments adjunct with acupuncture against acupuncture techniques. Furthermore, more than two therapies were simultaneously applied in the majority of the excluded trials, and thus evaluating the clinical effectiveness was either impossible or uninformative. Another concern about the excluded RCTs $(73 \%$ of Korean RCTs on acupuncture) was that various types of control groups were used, such as classical acupuncture, other therapies and no treatment at all. Since the overall clinical efficacy of acupuncture on many conditions remains controversial, this may not be a satisfactory approach for assessing the efficacy of specific acupuncture methods.

As noted earlier, the studies of acupuncture in Korea, reviewed here, have several methodological limitations. We highlight some of the difficulties inherent in research on acupuncture and offer some suggestions for future research. First, appropriate randomization was described in only four trials (about 12\%, one trial was included in this review and three were in excluded trials because of not fitting to inclusion criteria) and allocation concealment in only one of the RCT trials on acupuncture published in Korean literature. These are likely to show exaggerated treatment effects. Furthermore, most of the trials have neither adequate sample sizes nor sufficient statistical powers, often resulting in negative findings (Type II errors). Hence, a more rigorous methodology should be applied to future studies. Second, in an effort to explain non-specific effects, various sham acupuncture methods have been used. The success of blinding was checked in only one study. To reliably account for the placebo effect, it is crucial that the sham procedure be indistinguishable from the real treatment. Therefore, the success of the blinding procedures should be assessed. Third, as noted, comparing one type of acupuncture to another without ensuring appropriate controls can lead us nowhere. Carrying out studies with comparable controls would be one way to establish or contribute to the current evidence of acupuncture.

This systematic review has several limitations. Although we attempted to retrieve all relevant RCTs, we cannot be certain that our searches were all inclusive. In fact, Korean databases may have incorrectly reported results and several early papers missing from the search. Moreover, some acupuncture trials may have been published in journals not listed in any electronic database. The distorting effects arising from publication bias and location bias are well documented (21-24). Further problems include the paucity and often suboptimal quality of the primary data.

In conclusion, because more than two therapies were simultaneously assessed in the majority of the allegeable trials, evaluated RCTs represented only a small portion of RCTs that have been published in Korean literature. The contributions to the current evidence are limited in cases of on premenstrual syndrome, shoulder pain and low back pain. However, well-designed RCTs of acupuncture with rigorous methodology are in progress or have been completed at several institutions through funding from the Korean government. Thus, acupuncture research from Korea will contribute to establish or contribute to progress in the field.

\section{Supplementary Data}

Supplementary data are available at eCAM Online.

\section{Acknowledgement}

This study was supported by Wonkwang University (2007).

\section{References}

1. Ernst E, Pittler MH, Wider B, Boddy K. The Desktop Guide to Complementary and Alternative Medicine. Edinburgh: Mosby/ Elservier, 2006.

2. Ernst E. Acupuncture-a critical analysis. $J$ Intern Med 2006;259:125-37.

3. Kim YS, Jun H, Chae Y, Park HJ, Kim BH, Chang IM, et al. The practice of Korean medicine: an overview of clinical trials in acupuncture. Evid Based Complement Alternat Med 2005;2:325-52.

4. Yin C, Park HJ, Chae Y, Ha E, Park HK, Lee HS, et al. Korean acupuncture: the individualized and practical acupuncture. Neurol Res 2007;29 (Suppl 1): S10-5.

5. Jadad AR, Moore RA, Carroll D, Jenkinson C, Reynolds DJ, Gavaghan DJ, et al. Assessing the quality of reports of randomized clinical trials: is blinding necessary? Control Clin Trials 1996;17: $1-12$.

6. White AR, Ernst E. A systematic review of randomized controlled trials of acupuncture for neck pain. Rheumatology (Oxford) 1999;38:143-7.

7. The Cochrane Collaboration. Cochrane Handbook for Systematic Reviews of Interventions The Cochrane Collaboration, 2006. Available at http://www.cochrane.org/resources/handbook (Accessed date 1 June 2007).

8. Melchart D, Linde K, Berman B, White A, Vickers A, Allais G, et al. Acupuncture for idiopathic headache. Cochrane Database of Systematic Reviews 2001:Art. No.: CD001218. DOI: 10.1002/ 14651858.CD001218.

9. Kim SC, Kim SN, Lim JA, Choi CM, Shim EK, Koo ST, et al. Effects of acupuncture treatment on the premenstrual syndrome: controlled clinical trial [in Korean]. J Korean Acupunct Mox Soc 2005;22:41-60.

10. Kwon YD, Lee SG, Lee CW, Jung SK, Kim DE, Choi SM. The short-term efficacy of acupuncture for chronic low back pain: randomized sham controlled trial. J Orient Rehab Med 2007;17: $123-32$.

11. Lee H, Hong KE, Kim YI, Yim YK, Ahn TW, Kang WC, et al. A clinical trial of acupuncture treatment for frozen shoulder [in Korean]. J Korean Acupunct Mox Soc 2006;23:165-77.

12. Park YC, Jo JH, Hong KE, Kang WC, Choi SM. Effect of acupuncture on nasal obstruction in patients with persistent allergic rhinitis: a randomized controlled trial [in Korean]. $J$ Korean Acupunct Mox Soc 2005;22:229-39.

13. Cho KS, Kim SC, Lee JY, Sohn SS, Park DS. The effect of acupuncture on the post-thoracotomy pain control [in Korean]. Korean J Thorac Cardiovasc Surg 1997:30:187-94.

14. Choi DY, Lim S, Cha NH, Kim KS, Lee SH, Kim SY, et al. Effects on pain behavior in non-medicinal treatment applied to chronic headache patients [in Korean]. Korean $J$ Meridian Acupoint 2005;22:55-66. 
15. Yuk SS, Lim EM. A clinical study on the effect of crossing over treatment of acupuncture and herbal medication for primary dysmenorrhea [in Korean]. J Orient Obstet Gynaecol 2005;18: $144-52$.

16. Kim YS, Kim $\mathrm{CH}$, Kim KS. Effect of auricular acupuncture on postoperative nausea and vomiting. $J$ Korean Orient Med 1996;17:331-6.

17. Park TS, Park JS, Ko MY. A clinical effect of electro-acupuncture stimulation therapy on TMD patients. $J$ Korean Acad Craniomandibular Disorders 1999;11:103-11.

18. Sok SH, Kim KB. The effect of auricular acupuncture pressure therapy on insomnia of elderly people [in Korean]. $J$ Korean Acad Soc Adult Nurs 2000;12:222-33.
19. Ernst E, Pittler MH, Wider B, Boddy K. Acupuncture: its evidencebase is changing. Am J Chin Med 2007;35:21-5.

20. Chernyak GV, Sessler DI. Perioperative acupuncture and related techniques. Anesthesiology 2005;102:1031-49; quiz 77-8.

21. Dickersin K. The existence of publication bias and risk factors for its occurrence. JAMA 1990;263:1385-9.

22. Egger M, Smith GD. Bias in location and selection of studies. Br Med J 1998;316:61-6.

23. Ernst E, Pittler MH. Alternative therapy bias. Nature 1997;385:480.

24. Pittler MH, Abbot NC, Harkness EF, Ernst E. Location bias in controlled clinical trials of complementary/alternative therapies. $J$ Clin Epidemiol 2000;53:485-9.

Received November 29, 2006; accepted July 23, 2007 


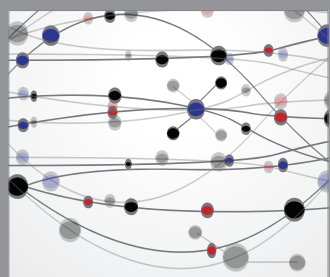

The Scientific World Journal
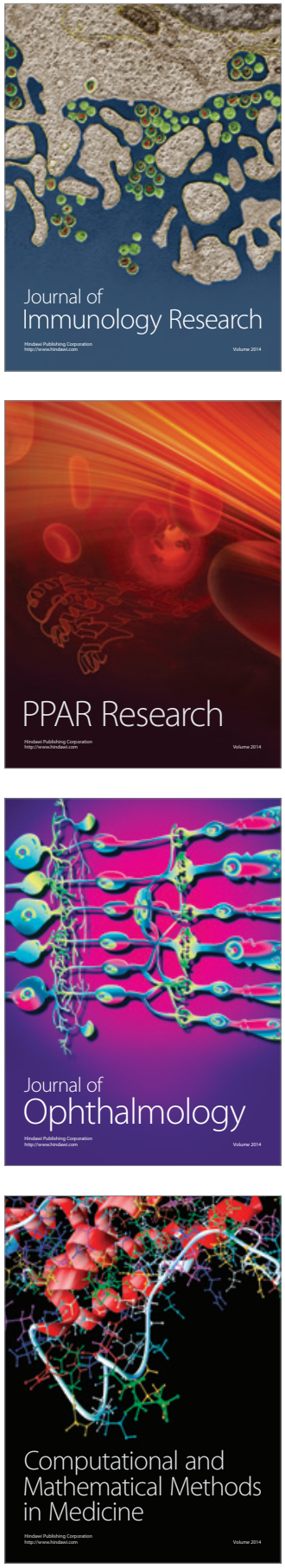

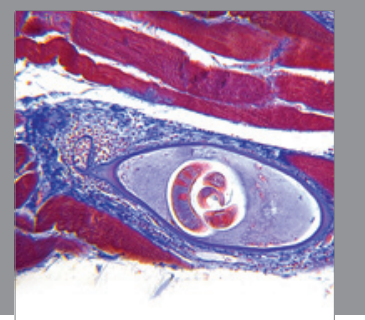

Gastroenterology

Research and Practice
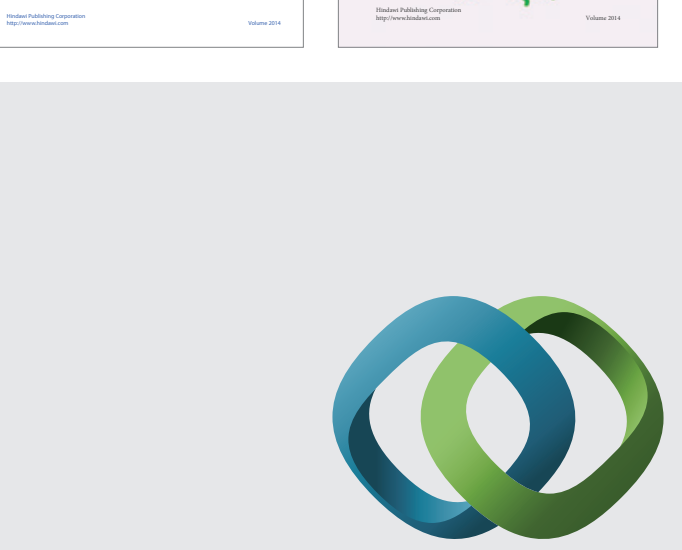

\section{Hindawi}

Submit your manuscripts at

http://www.hindawi.com
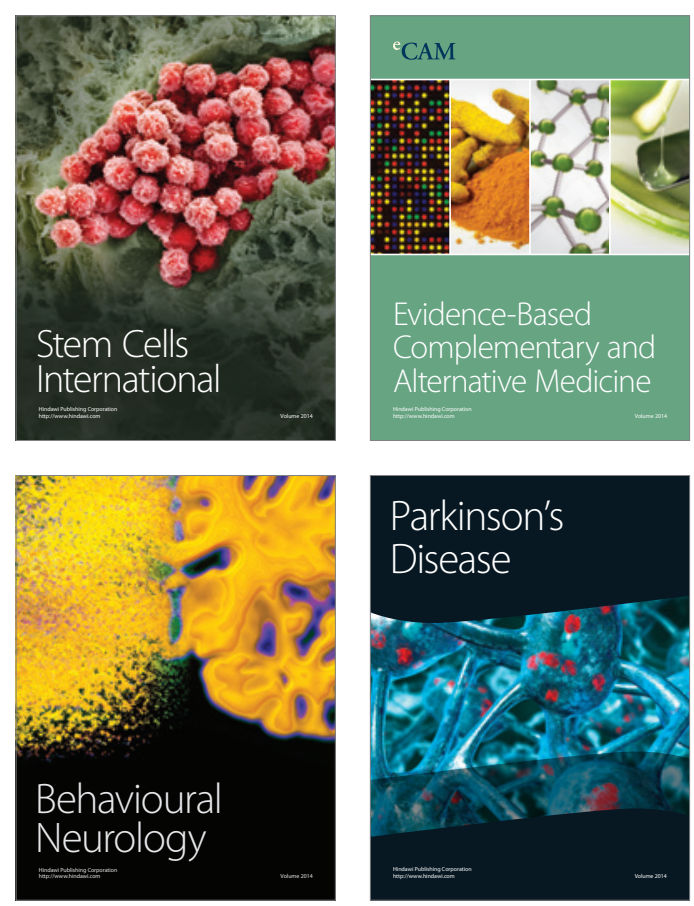

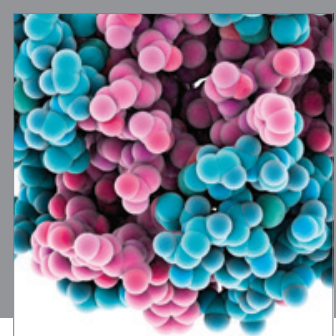

Journal of
Diabetes Research

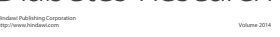

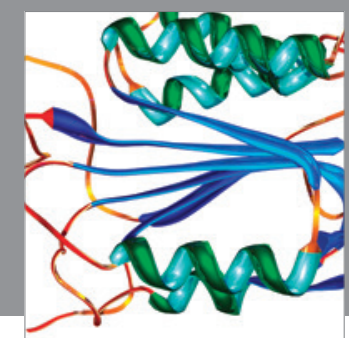

Disease Markers
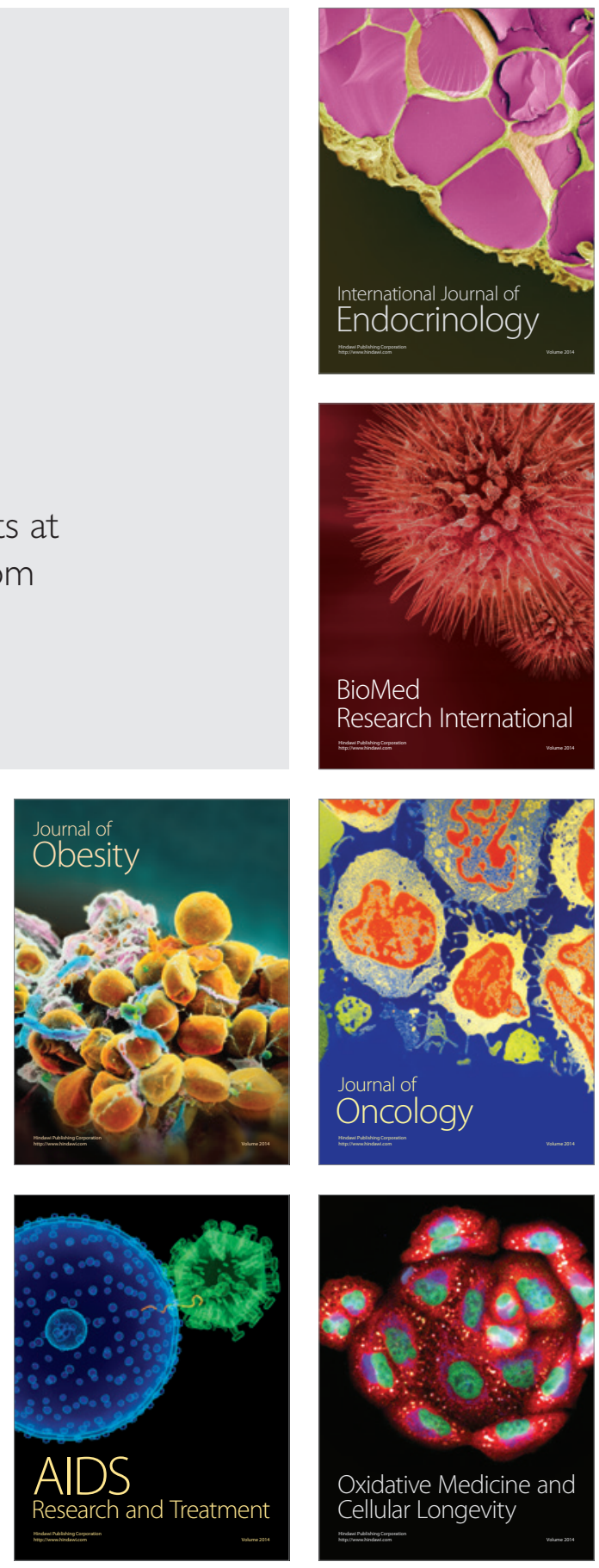